\title{
DESENVOLVIMENTO DE RESISTÊNCIA BACTERIANA POR MOLÉCULAS NÃO ANTIBIÓTICAS
}

DEVELOPMENT OF BACTERIAL RESISTANCE BY NON-ANTIBIOTIC MOLECULES

\author{
SILVA, Liliam Sousa ${ }^{1}$; JESUS, Marleide da Silva ${ }^{1}$; TAKETANI, Natália Franco ${ }^{2}$; \\ ${ }^{1}$ Aluno(s) do Curso de Farmácia, Universidade São Francisco, Campus Swift Campinas; \\ ${ }^{2}$ Professor Orientador, Curso de Farmácia - Universidade São Francisco. \\ liliamsousas@gmail.com
}

RESUMO. A resistência bacteriana é considerada um dos maiores problemas de saúde pública mundial, e sua evolução é uma questão multifacetada e influenciada por diversos fatores. A falta de compreensão para os perigos potenciais e o uso inadequado constitui um conjunto de definições que vareia de prescrição desnecessária de antibióticos a dose incorreta que podem ter levado ao estado atual dessa crise. O processo natural de resistência existe há muitos anos, contudo a necessidade usual dessas drogas nos levou a uma desvantagem ambiental grande, resultado de anos de pressão de seleção de aplicações humanas de antibióticos e este cenário leva o processo de resistência bacteriana a um nível não natural. Considerando-se que a resistência bacteriana é uma questão seria e preocupante, é passível questionar se existe a possibilidade de outras moléculas estarem envolvidas como aceleradores ou até mesmo indutores dessa resistência. Neste trabalho através de uma revisão da bibliografia pretendemos responder essa questão e ampliar o olhar frente a essa possibilidade. A evolução e disseminação da resistência aos antibióticos dependem da pressão antibiótica exercida no ambiente microbiano, quando mais de um antibiótico está presente no ambiente, a pressão seletiva produz variantes bacterianas que utilizam mecanismos múltiplos ou aperfeiçoam um mecanismo único de resistência para sobreviver sob as condições ambientais adversas. Considerando essa evolução estudos sugerem que a fluoxetina e o triclosan são indutores de resistência bacteriana e através de vários experimentos foi possível comprovar tal afirmação. Isso demonstra uma tendenciosa preocupação, já que além dos antibióticos serem os principais indutores, temos mais moléculas que colaboram com o aumento da resistência.

Palavras-chave: Resistência bacteriana, antibióticos, antidepressivos, fluoxetina, triclosan.

ABSTRACT. Bacterial resistance is considered one of the greatest problems of public health in the world, and its evolution is a multifaceted issue and influenced by several factors. Lack of understanding for potential hazards and misuse is a set of definitions ranging from unnecessary prescription of antibiotics to the incorrect dose that may have led to the current state of this crisis. The natural process of resistance has existed for many years, yet the usual need for these drugs has led us to a major environmental disadvantage, the result of years of selection pressure of human antibiotic applications and this scenario takes the process of bacterial resistance to an unnatural level. Considering that bacterial resistance is a serious and worrying issue, it is questionable whether there is the possibility that other molecules are involved as accelerators or even inducers of this resistance. In this work, through a review of the bibliography, we intend to answer this question and broaden our view on this possibility. The evolution and spread of antibiotic resistance depend on the antibiotic pressure exerted in the microbial environment, when more than one antibiotic is present in the environment, selective pressure produces bacterial variants that use multiple mechanisms or perfect a single 


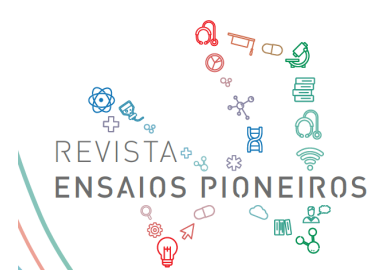

mechanism of resistance to survive under environmental conditions adverse effects. Considering this evolution studies suggest that fluoxetine and triclosan are inducers of bacterial resistance and through several experiments it was possible to prove such an assertion. This shows a biased concern, since in addition to antibiotics being the main inducers, we have more molecules that help increase resistance.

Keywords: Bacterial resistance, antibiotics, antidepressants, fluoxetine, triclosan.

\section{INTRODUÇÃO}

A resistência bacteriana é considerada um dos maiores problemas de saúde pública mundial (MARTINS et al., 2018). A evolução da resistência bacteriana é uma questão multifacetada que é influenciada por diversos fatores. O uso excessivo de antibióticos é geralmente considerado como o principal fator que contribui para isso (JIN et al., 2018). Esse crescente problema de saúde impactou significativamente o bem estar público e sobrecarregou substancialmente o sistema econômico em escala global (HWANG; GUMS, 2016). A resistência antimicrobiana surgiu em meio às preocupações com a saúde pública durante o século XXI. De acordo com o Centro de Controle e Prevenção de Doenças (CDC) em 2013, pelo menos 2 milhões de pessoas nos Estados Unidos ficaram seriamente infectadas com bactérias resistentes a pelo menos um antibiótico normalmente usado para tratar infecções, e pelo menos 23.000 pessoas morreram diretamente devido a infecções resistentes a antibióticos (CDC, 2013).

A falta de compreensão para os perigos potenciais e o uso inadequado constitui um conjunto de definições, variando de prescrição desnecessária de antibióticos a dose incorreta ou uso de drogas, assim como o uso indiscriminado de antimicrobianos, levou ao estado dessa crise de resistência bacteriana (HWANG; GUMS, 2016). Quando os antibióticos foram introduzidos pela primeira vez na medicina há cerca de 70 anos, a razão da dosagem era relativamente simples: obter uma dose terapêutica no local infectado que fosse alta o suficiente para eliminar a infecção bacteriana sem ter um efeito tóxico grave no paciente (ANDERSSON; HUGHES, 2014).

Embora bactérias resistentes a altas concentrações de antibióticos pudessem ser facilmente selecionados in vitro, a baixa probabilidade de encontrar infecções resistentes em situações clínicas, combinada com a disponibilidade de antibióticos eficazes alternativos, significava que o sucesso terapêutico poderia ser alcançado na maioria das situações clínicas até o passado (ANDERSSON; HUGHES, 2014). O processo natural de resistência existe nos micróbios há muitos anos, evidências sugerem que os elementos de resistência identificados no DNA bacteriano poderiam ser rastreados a milhares de anos. Desde a introdução da penicilina, as bactérias desenvolveram mecanismos para combater os antibióticos para sua própria sobrevivência. E o surgimento de fatores para a resistência antimicrobiana é em parte o resultado de um processo evolutivo de adaptação microbiana e seleção natural (HWANG; GUMS, 2016).

Contudo a necessidade usual dessas drogas nos levou a uma grande desvantagem ambiental, desde a sua introdução milhões de toneladas de antibióticos já foram produzidas e empregadas em uma variedade de aplicações, desde o uso para tratamento correto, prescrições inadequadas, agropecuária entre outras aplicações, podemos considerar que o planeta está saturado por esses agentes tóxicos, o que, é claro, contribuiu significativamente para a seleção de cepas resistentes. A partir disto, o desenvolvimento de gerações de micro-organismos resistentes a antibióticos em toda a biosfera é resultado de anos de pressão de seleção de 
aplicações humanas de antibióticos, e este cenário não é um processo natural, mas sim um processo artificial sobreposto à natureza que por ação exclusivamente humana nos levou a condição atual de resistência (DAVIES, 1996).

Entretanto é necessário salientar sobre os diversos mecanismos de resistência desenvolvidos pelas bactérias. A resistência aos antibióticos é codificada por vários genes, muitos dos quais podem ser transferidos entre bactérias. Novos mecanismos de resistência são constantemente descritos e novos genes e vetores de transmissão são identificados regularmente, e esses mecanismos são considerados processos evolutivos (BLAIR et al., 2015).

As bactérias podem ser intrinsecamente resistentes a certos antibióticos, mas também podem adquirir resistência por meio de mutações em genes cromossômicos e por transferência horizontal de genes. A resistência intrínseca de uma espécie bacteriana a um antibiótico particular é a capacidade de resistir à ação desse antibiótico, como resultado de características estruturais ou funcionais, onde não existe um mecanismo específico que impeça a ação de determinado antibiótico, mas sim mecanismos estruturais que qualquer antibiótico viria ter dificuldades de ação ou ate mesmo nenhuma ação terapêutica, as bactérias também podem adquirir ou desenvolver outros mecanismos de resistência, que de modo geral estão divido em três grupos, sendo: aqueles que minimizam as concentrações intracelulares do antibiótico, como resultado da penetração deficiente na bactéria ou do efluxo de antibióticos; os que modificam o alvo antibiótico por mutação genética ou modificação pós-traducional do alvo; e os que inativam o antibiótico por hidrólise ou modificação (BLAIR et al.,2015).

No mecanismo de diminuição das concentrações intracelulares pela penetração deficiente do antibiótico se define pela redução da permeabilidade, onde ocorre a diminuição na expressão dos canais de porinas que são proteínas da membrana externa ou pela substituição das porinas por canais mais seletivos, e pela atividade das bombas de efluxo que transportam muitos antibióticos para fora da célula, quando super expressadas essas bombas de efluxo se torna um dos principais mecanismos de resistência bacteriana. O segundo grupo que modifica o alvo antibiótico por mutação genica ou modificação pós-traducional pode desenvolver-se por mutação do local alvo (por exemplo, como encontrado em mutações em genes de enzimas topoisomerase que em muitas espécies conferem resistência a fluoroquinolona) ou recombinação para promover um alelo de mosaico (como encontrado nas proteínas de ligação à penicilina em mosaico em pneumococos e gonococos que conferem $\beta$ lactâmicos resistentes) resulta em um alvo funcional com reduzida afinidade pelo antibiótico, que não se liga eficientemente e, portanto, tem um efeito reduzido ou desprezível. Outra alteração dentro das modificações de alvos é a aquisição de um gene homólogo ao alvo original. A proteção por modificação do alvo também pode ser um meio eficaz de resistência a antibióticos que não requerem uma mudança mutacional nos genes que codificam as moléculas alvo, a proteção de alvos foi considerada um mecanismo clinicamente relevante de resistência para vários antibióticos importantes (BLAIR et al.,2015).

No terceiro grupo de mecanismos está à modificação direta de antibióticos que além de impedir que entrem na célula ou alterem seus alvos, as bactérias podem destruir ou modifica-los, resistindo assim à sua ação. Nesse contexto está incluída a modificação enzimática, considerada também como um dos principais mecanismos de resistência, onde enzimas bacterianas podem degradar ou modificar antibióticos de diferentes classes ou até mesmo dentro da mesma classe. E não menos importante a adição de grupos químicos a sítios vulneráveis na molécula de antibiótico por enzimas bacterianas que causam resistência, impedindo que o antibiótico se ligue à sua proteína alvo (BLAIR et al.,2015). 


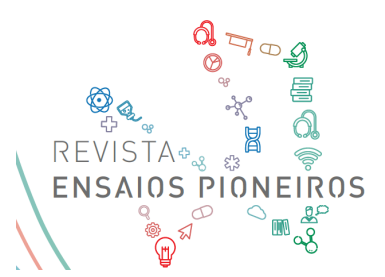

Essas informações, se utilizadas adequadamente, devem auxiliar na descoberta e desenvolvimento de novos agentes que possam contornar ou neutralizar os mecanismos de resistência (BLAIR et al., 2015).

Um estudo recente que monitorou a resistência antimicrobiana global baseada em amostras de esgoto urbano demonstrou que os dados sobre o uso de antibiótico e a taxonomia bacteriana explicam somente uma pequena parcela da variação da resistência que é observada recentemente. A grande incidência de genes de resistência bacteriana está fortemente relacionada com fatores socioeconômicos, de saúde e ambiental o que reforça a questão do comportamento humano quanto ao uso de antibióticos e que a diversidade e abundância de genes de resistência variam de acordo com a região, a melhoria do saneamento básico e da saúde poderia auxiliar a limitar a carga global de resistência bacteriana (HENDRIKSEN et $a l .$, .

O atual estado de resistência bacteriana é considerado extremamente complicado, e se as tendências na evolução da resistência continuar ou até mesmo piorar uma "era pósantibiótica" pode ser uma possibilidade considerável em um futuro próximo (HWANG; GUMS, 2016). Embora falar da "era pós-antibiótico" esteja em grande parte exagerado, há pouca dúvida de que estamos entrando em uma era em que os futuros ganhos em terapia antimicrobiana virão em incrementos modestos na melhor das hipóteses (RICE, 2009). Varias estratégias foram desenvolvidas nos últimos anos para retardar essa progressão e combater as preocupações crescentes de resistência antimicrobiana. Tais estratégias se concentraram na implementação de programas de manejo antimicrobiano, evitando o uso indevido de antibióticos e promovendo a descoberta de novos agentes antimicrobianos (HWANG; GUMS, 2016).

Portanto, nunca foi tão importante compreendermos detalhadamente os mecanismos e as vias de resistência em bactérias patogênicas, de modo que possamos ajustar nosso comportamento clínico de maneira que minimizem o crescimento futuro da resistência. Diminuindo a pressão seletiva por meio do uso mais criterioso de antibióticos, podemos ser capazes de manter padrões de suscetibilidade antibiótica em um nível com o qual todos possam conviver (RICE, 2009).

Considerando-se que a resistência aos antibióticos é uma questão seria e preocupante, e que ocorre por uma situação natural quando visualizamos apenas o desenvolvimento dos microrganismos, é passível questionar se existem possibilidades diferentes de acelerar, contribuir ou até mesmo induzir a resistência bacteriana por outras moléculas ou substâncias. Portanto o objetivo desse trabalho é avaliar a existência de moléculas não antibióticas no aumento da resistência bacteriana.

\section{METODOLOGIA}

Nesse trabalho foi utilizado o método de revisão bibliográfica, para tal foram utilizadas as plataformas do Google Acadêmico, Revistas Científicas Internacionais (Elsevier, Nature) com as palavras chaves: antibióticos, resistência bacteriana, fluoxetina, triclosan, mecanismos de resistência. No período de março de 2018 a janeiro de 2019, foram analisados 28 artigos científicos onde quinze deles mostraram-se significativos para o desenvolvimento deste estudo e treze artigos não foram considerados relevantes.

Os dados utilizados são em maioria estudos recentes já que consideramos os resultados desta revisão uma novidade para a sociedade, alguns dos textos revisados considerados antigos não abordavam o questionamento proposto, mas não foram completamente descartados, pois possuíam dados comprovados. 


\section{RESULTADOS E DISCUSSÃO}

A evolução e disseminação da resistência aos antibióticos dependem da pressão antibiótica exercida no ambiente microbiano, quando mais de um antibiótico está presente no ambiente, a pressão seletiva produz variantes bacterianas que utilizam mecanismos múltiplos, polivalentes ou aperfeiçoam um mecanismo único de resistência para sobreviver sob as condições ambientais adversas. Essa evolução precoce e a disseminação dos determinantes de resistência são o resultado das forças seletivas exercidas pelos antibióticos produzidos naturalmente. A quantidade extremamente baixa de antibióticos produzidos em circunstâncias naturais e efetivamente presente em ambientes altamente diluídos, como solo ou água, tem sido considerada um dos fatores que desafiam a importância de tais forças seletivas. É difícil conceber que muitos dos mais eficientes mecanismos de resistência atualmente detectados em bactérias multirresistentes, como as que ameaçam a saúde pública, possam ter se originado nesses ambientes naturais. Certamente, a maioria dos dados apoia o conceito de que a resistência a antibióticos apareceu somente após o surgimento de fortes forças seletivas resultante do uso massivo de antibióticos industrializados na medicina clínica e como suplementos alimentares para animais de fazenda entre diversas outras aplicações (BAQUERO; NEGRI, 1998).

Contudo estudos recentes apontam que além dos mecanismos que temos conhecimento outras fontes de contribuição à resistência bacteriana estão mais do que presentes em nosso cotidiano, e em escala global, os produtos químicos não antibióticos são usados em quantidades muito maiores do que os antibióticos, resultando em altos níveis residuais de substancias químicas no ambiente (LU et al.,2018).

Um estudo recente apontou que o uso de triclosan atualmente encontrado em diversos produtos está relacionado à indução de resistência bacteriana. Seu uso se expandiu para sabonetes, lancheiras, enxaguatórios bucais, géis de banho, géis de barbear, brinquedos, tabuas de corte, entre outros produtos por ter seu ponto de ebulição alto $\left(280-290^{\circ} \mathrm{C}\right)$. A via de exposição ao triclosan é complexa e envolvem muitos caminhos, estes caminhos destacam o potencial de exposição a baixos níveis de triclosan, o que poderia aumentar o risco de desenvolvimento a resistência. A maioria dos produtos que contém triclosan é arrastada pelo ralo e acabam em nossos cursos de água, o triclosan em ambientes aquáticos torna-se mais concentrado à medida que se aproxima das estações de tratamento de águas residuais. Embora as estações de tratamento de efluentes sejam eficazes na remoção da maioria do triclosan que entra, uma proporção dele pode permanecer no meio ambiente (GIULIANO; RYBAK, 2015).

Um estudo avaliou a ação do triclosan em uma concentração ambiental relevante $(0,2$ $\mathrm{mg} / \mathrm{L}$ ), pode induzir resistência a múltiplas drogas via estresse oxidativo com alta estabilidade hereditária. A mudança genética e a resposta transcriptômica global da Escherichia coli foram investigadas com base na sequência de DNA e RNA do genoma, respectivamente. Foram identificados determinantes críticos no surgimento de resistência a múltiplas drogas induzida pela exposição ao triclosan. O estresse oxidativo induzido pelo triclosan resultou em mutações genéticas em alguns genes, além disso, a transcrição dos genes que codificam as beta-lactamases e as bombas de efluxo de múltiplos fármacos foi significativamente regulada, enquanto a expressão de genes relacionados com a permeabilidade da membrana foi regulada negativamente, os resultados estão na figura 1 (LU et al.,2018). 


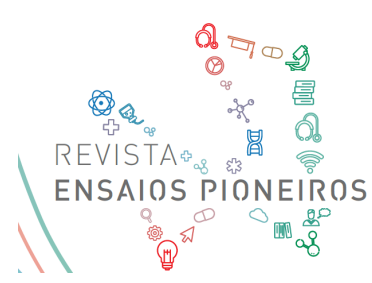

http://ensaiospioneiros.usf.edu.br

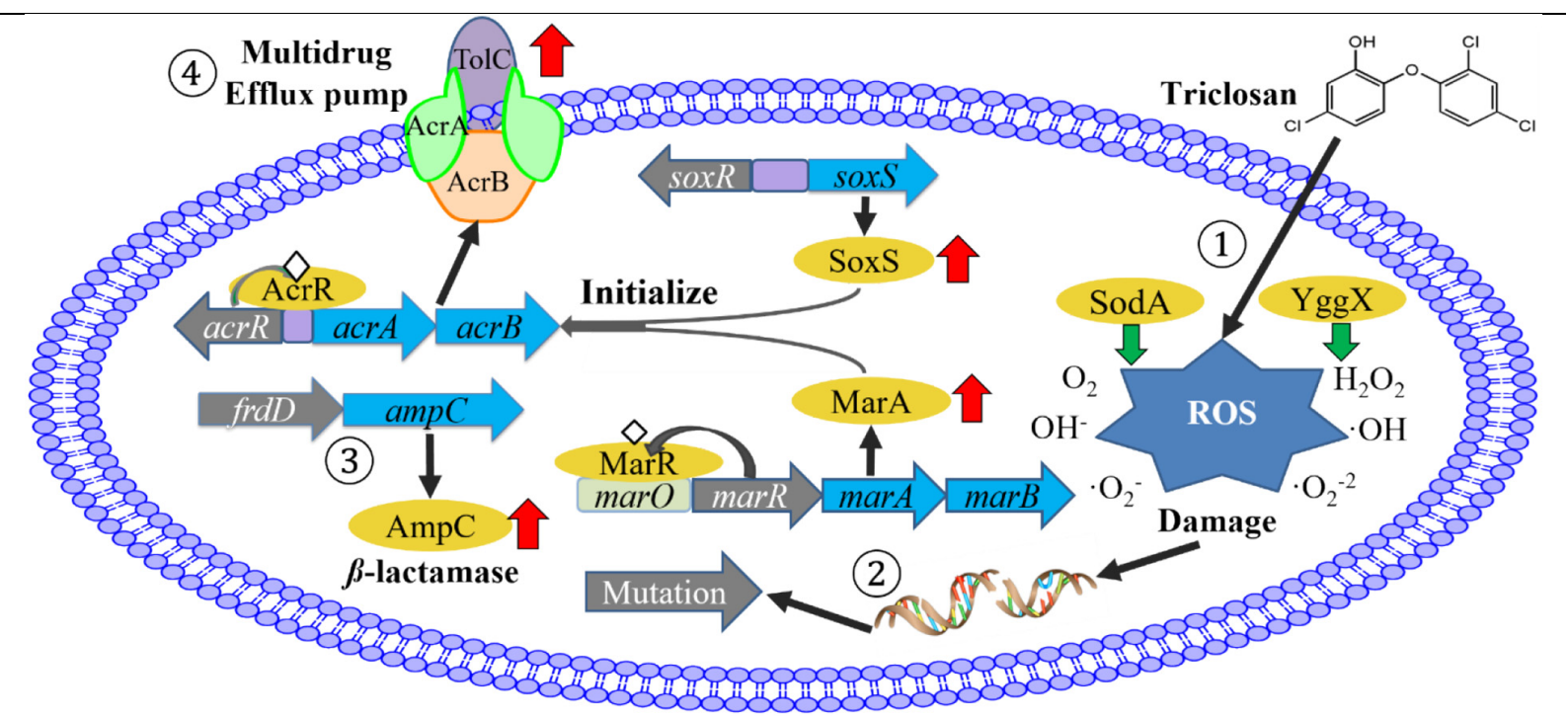

Figura 1 - O mecanismo proposto de resistência aos antibióticos induzida por Triclosan.

(Fonte: LU et al., 2018)

O Triclosan causou as múltiplas respostas em E. coli, incluindo: 1) o Triclosan causa geração aguda de EROs ao diminuir a expressão de genes que codificam antioxidantes celulares; 2) estresse oxidativo gerado pelo Triclosan pode induzir mutações genéticas; 3) consequentemente, as mutações genéticas levam à superexpressão do gene codificador da beta-lactamase; ou 4) expressão aumentada de genes reguladores globais e locais de múltiplas drogas que iniciam a expressão de bombas de efluxo de múltiplas drogas. Assim, os mutantes poderiam expressar extraordinária resistência hereditária a uma ampla gama de antibióticos, aumentando o efluxo de antibióticos e a degradação de antibióticos. A seta cinzenta representa mutações genéticas, a elipse amarela representa uma proteína e o diamante branco significa uma perda da função da proteína. A seta verde representa a expressão gênica diminuída, a seta vermelha indica um gene regulado para cima. Portanto podemos considerar que há uma série de diferentes questões envolvendo o uso de triclosan que merecem atenção: subprodutos ambientais, potencial de bioacumulação, toxicidade para organismos aquáticos e os efeitos do triclosan estimulando bactérias para o desenvolvimento de resistência a antibióticos, estas questões são importantes para a salvaguarda da saúde humana, dos ecossistemas aquáticos e do meio ambiente (DANN; HONTELA, 2011).

Outro estudo que se destaca pela inesperada afirmação onde classes de medicamentos como antidepressivos estariam envolvidos como indutor de resistência bacteriana, sendo este a fluoxetina um inibidor seletivo da receptação de serotonina, utilizado para o tratamento da depressão entre outras aplicações (SOARES; MORENO; MORENO, 1999).

Através de estudos que abordavam a presença desse antidepressivo em águas residuais e que a sua presença nesses sistemas se da pelo fato da sua excreção ser em parte pela urina, despertou o interesse em estudar a possibilidade de esse fármaco induzir a resistência já que não havia estudos anteriores que comprovassem tal envolvimento (JIN et al., 2018).

Tendo como objetivo investigar se a exposição à fluoxetina causaria o surgimento de resistência aos antibióticos à bactéria $E$. coli, um patógeno oportunista no intestino humano e comum no meio aquático, foi escolhida para realizar o experimento. Após 30 dias de exposição à fluoxetina, bactérias resistentes a antibióticos foram isoladas e sua resistência a 8 


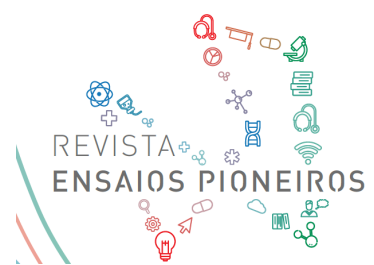

diferentes tipos de antibióticos foi determinada, juntamente com as medidas combinadas de produção de espécies reativas de oxigênio (EROs) estressadas pela fluoxetina. Os mecanismos de resistência a antibióticos induzidos por fluoxetina foram exaustivamente investigados por sequenciamento de DNA em todo o genoma, sequenciamento de RNA e perfil proteômico (JIN et al.,2018).

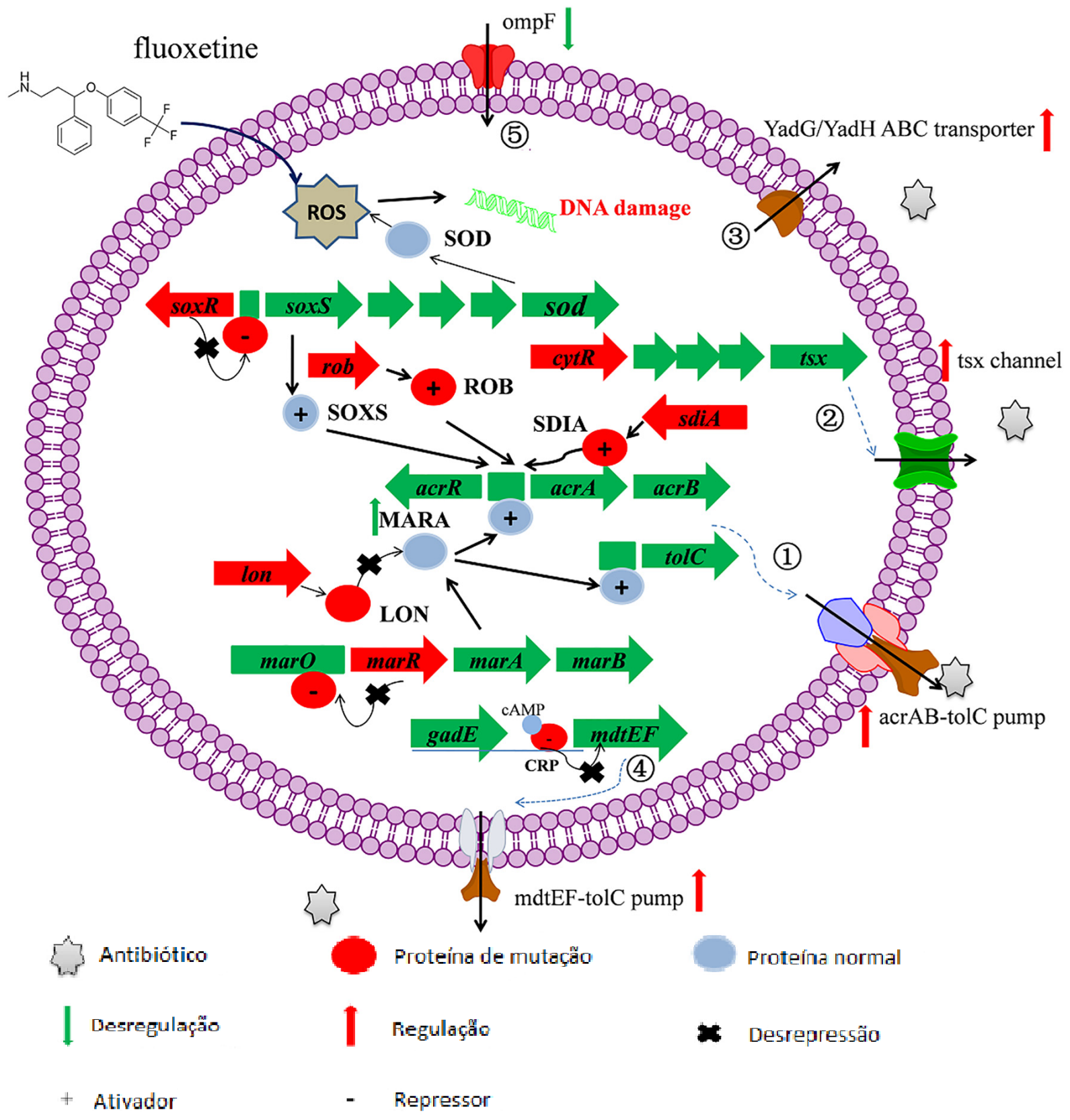

Figura 2 - Mecanismos hipotéticos de resistência contra múltiplos antibióticos ativados pela fluoxetina em mutantes de $E$. coli.

(Fonte: JIN et al., 2018)

Após diversos mecanismos de resistências terem sido evidenciados no experimento pode-se comprovar que o antidepressivo fluoxetina induz resistência multi-antibiótica provocada por mutagênese mediada por ROS. A frequência de mutações foi dramaticamente 


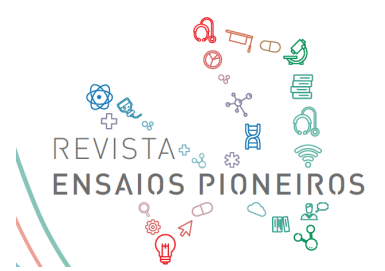

aumentada sob a exposição da fluoxetina. O sequenciamento de DNA, RNA e proteínas identificaram determinantes críticos no surgimento da resistência a múltiplas drogas induzida pela pressão de seleção da exposição à fluoxetina. É comprovado que a exposição frequente da fluoxetina levou principalmente a mutações cromossômicas (incluindo deleção, inserção e substituição de genes) que causaram a regulação alterada de genes que codificam um sistema de bomba de efluxo múltiplo. A superprodução de ROS induzida pela exposição de mutagênese mediada pelo antidepressivo fluoxetina em reguladores de transcrição de ligação a DNA, por exemplo, marR, rob, sdiA, cytR e crp, que podem resultar na superexpressão do sistema de efluxo de multidrogas e promover efluxo de antibióticos via AcrAB TolC bomba (1), canal Tsx (2), transportador YadG / H ABC (3) e a bomba MdtEF-TolC (4). A diminuição da proteína da porina da membrana externa OmpF 5 também pode ajudar a bloquear a entrada de antibióticos na célula, os resultados estão na figura 2 (JIN et al., 2018)

Por último e não menos importante através do estudo realizado pelo monitoramento global do esgoto humano foi observado que o uso de antimicrobianos explicou apenas uma pequena parte da ocorrência de resistência bacteriana em todo o mundo. Além disso, os dados do uso de antimicrobianos são difíceis de obter e estão sujeitos a limitações devido à falta de um sistema adequado de prescrição em muitos países. Nesse estudo foi considerado que o Índice de Desenvolvimento Humano (IDH) estava fortemente relacionado com a resistência bacteriana, devido à hipótese de vários outros fatores ligados ao IDH serem tanto indicadores quanto indutores para a resistência bacteriana (HENDRIKSEN et al., 2019).

a

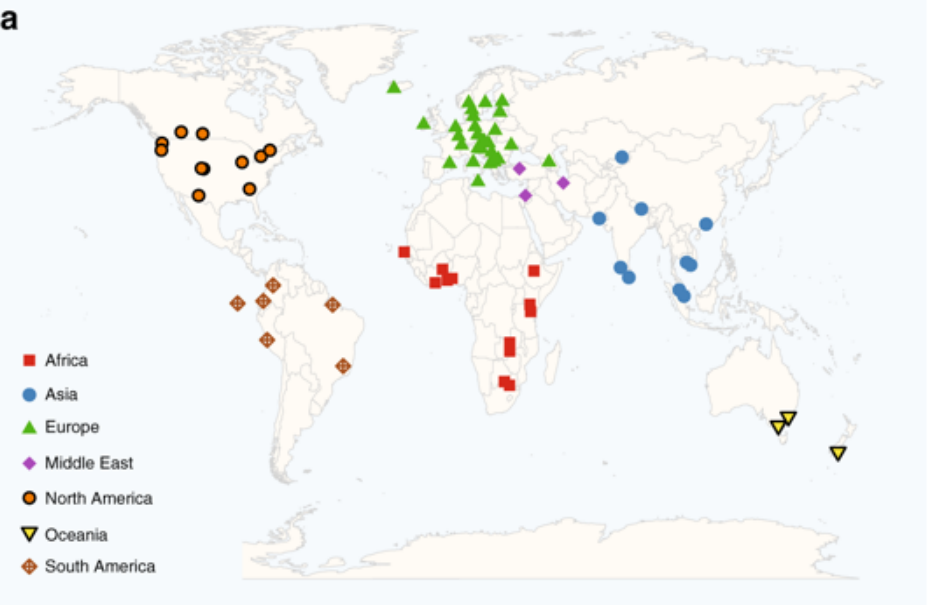

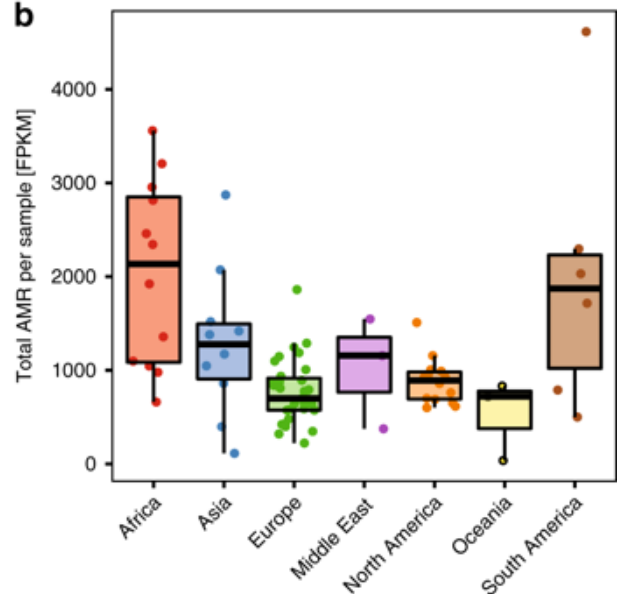

Figura 3 - a Locais globais de amostragem de esgoto e visão geral da abundância e composição da resistência antibiótica um mapa dos locais de amostragem. b Boxplots do total de fragmentos de resistência por base de quilo por milhão de fragmentos por amostra, estratificados por região (Fonte: HENDRIKSEN et al.,2019).

Os dados utilizados para a investigação dessas descobertas baseou-se em 1503 variáveis do Banco Mundial de Saúde, Nutrição e População, onde a maioria das variáveis associadas aos níveis de resistência bacteriana está relacionada ao saneamento básico e a saúde geral, o esgoto domestico foi coletado 79 locais de amostra, cobrindo sete regiões geográficas de 79 cidades em 60 países, apresentado na figura 3a. A abundância total de genes de resistência bacteriana variou entre locais e continentes, os maiores níveis de genes de resistência foram observados nos países Africanos (2034,3 fragmentos por quilo de base por milhão de fragmentos), embora o Brasil tenha a maior abundância de todos (4616,9 FPKM). 
No extremo inferior do espectro estavam Oceania (Nova Zelândia e Austrália) (Média: 529,5 FPKM), como demostra a figura 3b (HENDRIKSEN et al., 2019).

Uma base confiável de evidencias que descreva e caracterize com precisão a carga global e a transmissão da resistência bacteriana é essencial para apoiar o estabelecimento de prioridades nacionais e internacionais nas ações de saúde e decisões de tratamento correto e necessário (HENDRIKSEN et al.,2019).

Podemos considerar, portanto que a resistência bacteriana começa a ser questionada quanto a sua origem, pois populações com um menor índice de desenvolvimento estão sujeitas a maiores índices de resistência bacteriana e isso não necessariamente está ligado diretamente ao uso de antibióticos em tratamentos medicamentosos.

$\mathrm{O}$ estudo de monitoramento global do esgoto pretendeu representar também a primeira tentativa de monitorar e prever a ocorrência de resistência bacteriana na população humana global e predominantemente saudável, os resultados estão na figura 4 (HENDRIKSEN et al., 2019).

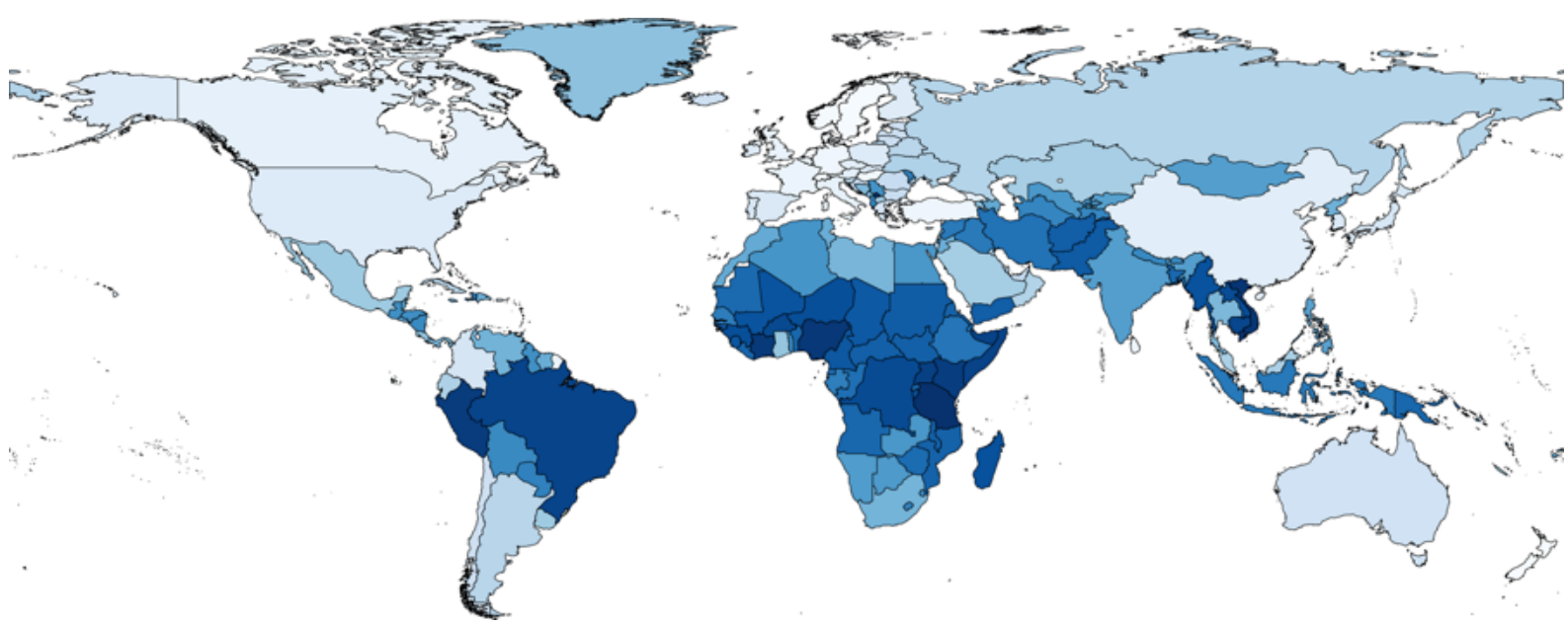

Figura 4 - Previsões globais de abundância de resistência antimicrobiana (AMR) em todos os países e territórios do mundo. Mapa colorido de acordo com a abundância (Fonte: HENDRIKSEN et al., 2019).

Portanto, através dos trabalhos apresentados na literatura científica podemos visualizar o efeito direto do esgoto e de substâncias poluentes no desenvolvimento de resistência bacteriana. Essas substâncias estão presentes de forma abundante principalmente em grandes concentrações populacionais no mundo e isso gera uma preocupação ainda mais significativa frente ao aumento de resistência bacteriana a substâncias não antibióticas. Sendo assim, a compreensão mais detalhada desses mecanismos de resistência é imprescindível para a contenção do aumento desse efeito nas populações microbianas, assim como, consequentemente o aumento de infecções multirresistentes que são tão importantes e cada vez mais significativas na população.

\section{CONCLUSÃO}

Concluímos, portanto que moléculas não antibióticas podem e são indutoras de resistência bacterina, isso demonstrou ser uma enorme e tendenciosa preocupação já que além dos próprios antibióticos serem os principais mecanismos pelos quais as bactérias se tornam resistentes damos a elas mais ferramentas de indução. Foi possível observar com esse estudo 
que precisamos desenvolver pesquisas que nos coloquem a frente dessas evoluções bacterianas e nos de mais opções de medicamentos que se sobreponham a esses mecanismos de resistência ou que possamos encontrar maneiras de diminuir os impactos dessas substâncias no ambiente diminuindo consequentemente a resistência bacteriana. Esperar por um cenário pós-antibiótico seria uma consequência catastrófica e possivelmente irreparável.

\section{REFERÊNCIAS}

ANDERSSON, D. I.; HUGHES, D. Microbiological effects of sublethal levels of antibiotics. Nature Publishing Group, n. May, p. 1-14, 2014.

BAQUERO, F.; NEGRI, M. Antibiotic-Selective Environments. v. 27, n. Suppl 1, p. 5-11, 1998.

BLAIR, J. M. A. et al. Molecular mechanisms of antibiotic resistance. Nature Reviews Microbiology, v. 13, n. 1, p. 42-51, 2015.

CDC Centers for Disease Control and Prevention. Antibiotic Resistance Threats in the United States, 2013. http://www.cdc.gov/drugresistance/threat-report-2013, (acesso em 21 de Abril de 2019).

DANN, A. B.; HONTELA, A. Triclosan: Environmental exposure, toxicity and mechanisms of action. Journal of Applied Toxicology, v. 31, n. 4, p. 285-311, 2011.

DAVIES, J. Origins and evolution of antibiotic resistance. Microbiologia (Madrid, Spain), v. 12, n. 1, p. 9-16, 1996.

HENDRIKSEN, R. S. et al. Global monitoring of antimicrobial resistance based on metagenomics analyses of urban sewage. Nature Communications, v. 10, n. 1, 2019.

HWANG, A. Y.; GUMS, J. G. The emergence and evolution of antimicrobial resistance: Impact on a global scale. Bioorganic and Medicinal Chemistry, v. 24, n. 24, p. 6440-6445, 2016.

JIN, M. et al. Antidepressant fluoxetine induces multiple antibiotics resistance in Escherichia coli via ROS-mediated mutagenesis. Environment International, v. 120, n. July, p. 421-430, 2018.

LU, J. et al. Non-antibiotic antimicrobial triclosan induces multiple antibiotic resistance through genetic mutation. Environment International, v. 118, n. February, p. 257-265, 2018. 
MARTINS, C. A. et al. Ficha catalográfica elaborada pela Biblioteca de Ciências Biomédicas / ICICT / FIOCRUZ - RJ, 2018.

RICE, L. B. The clinical consequences of antimicrobial resistance. p. 476-481, 2009.

SOARES, M. B. D. M.; MORENO, R. A.; MORENO, D. H. Psicofarmacologia de antidepressivos. Revista Brasileira de Psiquiatria, v. 21, p. 24-40, 1999. 